\title{
Sønderjyllands Stednavne.
}

\section{Af Peter Skautrup.}

\section{Kilderne.}

Tager vi begrebet $s$ te $\mathrm{d}$ a $\mathrm{v} n \mathrm{i}$ videste forstand, har der vel været stednavne til, så længe mennesket har levet. Man har fra første færd haft brug for naturbetegnende «navne«. Men først når vi får en fast bosættelse, kan der være tale om en fast navneoverlevering. En bys, en bygds geografiske betegnelser gror fast, overleveres fra slægt til slægt, føres videre gennem tradition og bliver, idet deres betydningsindhold meget ofte glemmes, lidt efter lidt til egentlige navne, proprier. Hvis traditionen brydes, f. ex. ved erobring, affolkning eller omflytning, kan et navnesæt gå tabt, og især da de naturbetegnende navne, marknavne og lignende. Det er min overbevisning, at udskiftningstiden noget før og omkring 1800 var en meget kritisk tid for vort marknavnestof. Da gik en stor mængde naturog marknavne i glemmebogen. Før udskiftningen kendte bonden alle landsbyens marker, man havde et stort fælleseje også $\mathbf{i}$ navnestoffet. Men efter udskiftningen blev den enkeltes horisont mindre, nu havde han vasentlig kun sin egen jord, og hans sted- og marknavnestof svandt ind. Brud på traditionen fandt også jæunlig sted ved efterkrigstidens stærk ๖ bỵtten gårde. Den gamle ejer tog sin viden, sit navnestof nied sig. Gården beholdt vel sit navn, men markerne lå navnløse hen. Således har det vel været alle dage, om end det nok navnlig er de sidste 200 år, at traditionsbrud har fundet sted. Vore marknavne har derfor gennemgående et noget yngre præg end begyggelsesnavnene, og det er ret sjældent, at vi kan føre naturnavnene langt tilbage. Dette beror dog muligvis på kildernes utilstrækkelighed. Kan vi føre et marknavn tilbage til tiden før udskiftningen, tør vi ikke benægte, at det kan være lige så gammelt som bebyggelsen på stedet, hvortil det hører, ja sprogligt kan vi for flere af disse marknavnes vedkommende 
fastslå, at de har lige så ærværdig en alder som vore ældre bebygggelsenavne. Tager vi f. ex. et middelstort sogn som Arrild (III. 63 ff.), har vi i "Sønderjyske Stednavne" registreret ialt 375 naturnavne, hvoraf de 272 er kendt i nutiden.) Af disse kan dog kun de 65 i skriftlige kilder føres tilbage til tiden før ca. 1800 , selv om der nok er nogle flere af de resterende $20 \%$ (f. ex. navne som Bjellumvej, Odsken, Skarrev o. fl.), som efter deres dannelse og form må være meget gamle. - Og omvendt: finder vi i en ældra overlevering nævnt natur- og marknavne, er det of te nu umuligt at stedfæste dem. På et eller andet tidspunkt er traditionen blevet brudt, navnene glemt. Af 6 marknavne fra Uder-Bjærgum, Vester Vedsted sogn: mylnætofth, brethæland, kinninghsakær, albæhøgh, a wænningh og buuthaker, som nævnes i en indførelse fra ca. 1300-1320 i Ribe Oldemoder, kan vi nu ikke stedfæste en eneste. - Hvor traditionen derimod har haft en størro kreds af bærere, hvad der i reglen vil være tilfældet for landskabs- og bebyggelsesnavnenes vedkommende, idet disse har været kendt ud over den nærmeste egn, vil vi som of test kunne følge navnene så langt tilbage, som vi har skriftlig overlevering.

Før de hjemlige kilder begynder at tale, finder vi enkelto danske - og for øvrigt især sønderjyske - stednavne nævnt i ældre fremmede kilder. Men nogen samlet fortegnolse over disse navne (væsentlig hos klassiske forfattere) har vi ikke. I F ör s t e m a n n: Altdeutsches Namenbuch (3. udg. 1913 -16) findes en del navne fra Sønderjylland. Folke- og stammenavne har vi samlede i S chönf eld s Wörterbuch der altgermanischen Personen- und Völkernamen' (1911). Også fra tiden efter at hjemlige kilder foreligger, findes en del dansk navnestof i fremmede rejsebeskrivelser, kortværker og lign. Således nogle navne - deriblandt $\mathrm{T} ø \mathrm{n} \mathrm{d}$ e $\mathrm{r}$ - på et verdenskort frem-

1) Hertil er dog også medregnet sådanne navne, som kun er attesteret fra den tyske matrikel. 
stillet af den arabiske geograf Idrisi (ca. 1138-5.1). ${ }^{1}$ ) Over navnestoffet i de norrone kilder (sagaer osv.) har vi kun en ufuldstændig liste i 12. bind af Formmanna Sögur (1837, p. $258 \mathrm{ff}$.).

Af de hjemlige kilder fra Middelalderen har runestenene så godt som ingen navne (fra sønclerjylland kun Hedeby). Hovedkilden er vore di p l o m e r, hvoraf en tidssvarende udgivelse (foreløbig indtil 1340) nu forestår. Foruden hovodværket $R$ e p e r t o r i u m Diplomaticum regni Danici mediævalis (1. række I-IV. 1894 ff; 2. række I-VII. 1928 ff., der går til 1513, men hvortil vi endnu meget savner et register) har for de sønderjyske navnes vedkommende især følgende diplomudgaver og brevbogsulgaver interesse: $\mathrm{S}$ ch les w ig-Hols te inLauenburgischo Regesten und Urkunden I-III $1884 \mathrm{ff}$., en meget fejlfuld udgave ved $\mathrm{Has}$ s e. - Rib e $\mathrm{O} I \mathrm{~d}$ emo d e r, et håndskrift (udg. ved Oluf Nielsen, 1869), hvori adkomstbreve (væsentlig dog $\mathrm{i}$ uddrag) for Ribe domkapitel og bispestol er indført. Løgumk os ter brevbog fra 1578 (trykt i Scriptores Rerum Danicarum VIII. ff., en noget forældet udgave) med afskrifter af breve vedrørende klostergodset. Diplomatarium Flensborgense I-II, en udgave af dokumenter med tilknytning til Flensborg (udg. af Seidelin 1865 ff.). En samling breve (til dels afskrifter) fra $\mathrm{H}$ a der $\mathrm{s}-$ lev domkapitel er trykt i Aarsberetn. fra Geheimearchivet II. Tilsvarende stof fra senere tider kan man finde $i$ det skriftlige nedslag fra herredstingene, men desværre er dette jo ikke tilgængeligt. St emann har i sin bog: Schleswig's Recht und Gerichtsverfassung im siebenzehnten Jahrhundert (1855) givet en lang rakke uddrag af herredstingsprotokollorne, men han har omhyggelig udeladt så godt som alle stedsangivelser; enkelte findes dog, og de burde have været excerperet til SS. ${ }^{2}$ ) - V'igtig er selvfølgelig også Kong V a l d emars J o r d e bog, om end den af sønderjysk stof egentlig kun giver herreds- og sognenavne. Videre Slesvigbispens

1) Namn och bygd 1931 p. 1ff. Jf. Sprog og Kultur I. 111, II. 70.

$\left.{ }^{2}\right)$ Således forkortes $\mathrm{i}$ det $\mathrm{flg}$. "Sonderjyske Stednavne«. 
J or d e b og fra diat 15. årh. (trykt i Scriptores VII. 456 ff. og i Quellensamml. der Schleswig-Holstein-Lauenburgischen Gesellschaft für vaterländische Gesch. VI).

Fra nyere tid er normalt $M$ a t $r$ ikle $\mathrm{r}$ e (med markbøgerne) hovedkilden, ${ }^{1}$ ) men for Sønderjylland er der det særforhold, at der i det 17. århundrede kun har funclet egentlig nıatrikuliring sted i de kongerigske dele $\mathrm{i}$ "de blandede distrikter" (hvorfor vi kun har markbogsstof fra Møgeltøuder, Daler, Visby, Emmerlev, Ballum, Randerup, Mjolden, Dastrup, Brede, Abild og Rømø)..") Den såkaldte "Renovirte Landes-Matricul" af 1642 for Slesvig-Holsten var jo ikke en matrikel i egentlig forstand (med opregning af de enkelte ejendomme osv.). En fuldstændig matrikel for Sønderjylland fik man først efter 1864. Den ty ske matrikel, med gode og nøjagtige kort over samtlige jorder og med angivelse af parcelgrænserne, blev fardig 1879. Men man kunde nok onske, at navnestoffet, som blev optaget $\mathrm{i}$ denne matrikel, var blevet gengivet på dansk og ikke i en stærkt fortysket form.

I mangel af ældre matrikler har man da i SS måttet udnytte, hvad der foreligger tilgængeligt af jor d ebøge $r$ fra ældre tid, og hvoraf en del er trykt i F. Falkenstjerne og Annz Hudes "Sønderjydske Skatte- og Jordeboger». Men navnestoffet her er $i$ virkeligheden ret ringe. Mere udbyttegivende er udskiftningsforretningerue fra slutningen af det 18. århundrede og lidt ind $\mathrm{i}$ det 19 . Hovedparten af de ældre navneformer i SS - mærket U, B. og L, d. v. s. udskiftnings-, boniterings- og landmålingssager - er fra dissc kilder.

Også i den topografiske litteratur fra xldre og nyere tid findes en del navnestof. Således fra det 17. ârhundrede på

1) Jf. Hjelholt: Den jydske Landmaalingsmatrikel, i Samılinger til jyclsk Historie og Topografi 4. R. III. $397 \mathrm{ff}$. - Gunnar Knurlsen: De wldre danske Matrikler, i Fortid og Nutid II. 1 ff. samt i Tidsskrift for Opmaalings- og Matrikulsvasen XII. (1931). - Jf. en kort oversigt i sprog og Kultur III. XX f.

2) Jf, J. L. Mosbech: Nogle Meddelelser om det aldre sønclerjydske Matrikulsvæen, i Tidsskr. for Opmaalings- og Matrikulsvæsen IX (1922), og: Matrikulsforhold Nord og Syd for Kongeaaen, i Sønrlerjydsk Maanedsskrift I. 65 ff., $82 \mathrm{ff}$. 
Johannes Mejers store kortarbejder i Caspar Danckwerths "Newe Landesbeschreibung der zwey Hertzogthümer Schleswich vnd Holstein « (1652; kortene fra årene forud), fra det 18. árh. i Pontop pidan s "Den Danske Atlas" bind VII (1781), og fra det 19. årh. i S c h rö ders (1837), T r a p s (1864) og O l d e ops (1906) topografiske værker, for at nævne de vigtigste. Hertil kommer navne fra kortværker som Jens $\mathrm{S} \emptyset$ rensens søkort (fra omkr. 1700), Videnskabernes Selskabs Kort (fra omkr. 1800) og Generalstabskortene (fra 1857 ff.).

Når vi hertil føjer stednavneordbogen hos K o k (Det danske Folkesprog i Sønderjylland II. 1867) og de postale stednavnefortegnelser i 0 rtschaftsverzeichnis 1890 og den danske Postadressebog (1921 og flg. udgaver) har vi vistnok nævnt de vigtigste historiske kilder.

Til dette på papir eller pergament fæstnede navnestof kommer så den leve nde tradition, det endnu kendte navnestof i mundtlig gengivelse på stedet. Da Stednavneudvalget $\mathrm{i}$ 1928 påbegyndte udarbejdelsen af det store værk om Sønderjyllands stednavne, havde det allerede - bl. a. fra arbejdet med fordanskningen eller rettere "aftyskningen« af danske stednavne i de fra Tyskland udleverede matrikelsprotokoller $\mathrm{m}$. $\mathrm{m}$. - liggende ikke så ganske få indberetninger fra lokale medarbejdere - landinspektører og andre - vedrørende navnestoffet. Dette materiale kompleteredes nu, og bortset fra nogle enkelte sogne i de første hæfter har man tillige sørget for at gennemføre en fuldstændig lydskriftoptegnelse af alle nu kendte stednavne, hvad der i høj grad oger arbejdets værdi. Dels kan de lydskrevne navne nemlig anvendes $i$ almindelige sproglige undersøgelser, og dels gør udtaleangivelserne det muligt ogsă for den ikke-stedkendte forsker at danne sig et skøn om den givne tolknings værdi. Dog mangler han i SS endnu et vigtigt hjæelpemiddel: et kort - eller i det mindste $i$ texten en stedshoskrivelse. Selv med et så fortræffeligt materiale, som nu er fremlagt i SS, er den private forsker ofte ladet temmelig i 
stikken. Han vil s e lokaliteten for sig, - for så vidt man endnu ved, hvor den er, og hvad den er. Hvad er Porsgejl (III. 116), Ravnholt (III. 117) og Toftum (III. 119) osv.? Er det lund, krat eller hede? Hvilken form har Pjag-en (III. 116) osv.? I de senere hæfter af SS synes man dog også fra redaktionens side at bestræbe sig for at give korte oplysninger herom. Kortbilag som f. ex. i Schmidt-Petersens Die Orts- und Flurnamen Nordfrieslands var det vel ikke til at forlange for så stort et område.

Så ligger nu hele dette store materiale foran os $\mathrm{i}$ » $\mathrm{S} ø \mathrm{n}$ d e rjyske Stednavne«, foreløbig Tønder og Aabenraa amter, bind III-IV, og i løbet af få år er hele varket afsluttet.

$\mathrm{S}$ t of $\mathrm{fet}$ er ordnet sognevis. Først anfores bebyggelsesnavnene, derefter naturnavnenø. Alt i alfabetisk rækkefølge. I Aabenraa amt og følgende bind har man yderligere delt naturnavnene, idet de anfores byvis inden for sognet. Efter opslagsformen følger (om navnet findes) nutidsudtalen, dorefter det historiske materiale og så en tolkning. De almindelige stednavneled, som kommer igen atter og atter, - altså især efterled - skal behandles $i$ et indledningsbind, hvad der udgivelsesmæssigt næppe er noget at sige til, hvorimod anmelderen eller brugeren - indtil dette indledningsbind foreligger -- rigtignok er temmelig handicappet $\mathbf{i}$ sit arbejde med stoffet.

"Sønderjyske Stednavne« er altsá en fuldstændig historisk stednavnefortegnelse eller stednavneordbog, hvor hvert enkelt navn er anført på topografisk-alfabetisk plads tillige med en tolkning.

Men hvad sâ, spørger man. Er vi dermed f:erdig med dette emne? Skal vi smakke bogen i og lade værket samle støv i hylden?

\section{Nej!}

Forst nu kan materialet nyttiggores - eller dog udnyttes. Først nu kan vi ud fra dette rige stof begynde at samle træk til landets, folkets og sprogets historie gennem det meste af et par tusinde år. Vi får igennem navnene besked om landets udscende og ovcrfladeforhold for og nu, land og vand, terræu- 
form og bevoksning, flora og fauna. F. ex. har plantegeografen brug for stednavnenes vidnesbyrd, - de kan formentlig for adskillige planters vedkommende udfylde tidsrummet mellem nutiden og den førhistoriske tid, om hvilken han gennem undersogelse af aflejringer eller ved pollenanalyser kan skaffe sig viden. - Stednavnene vidner videre for os om menneskeu es færd. Hvordan de gjorde sig jorden underdanig, ryddede skov og plojede ager. Hvorledes de byggede gård og by, torp og kåd. Hvad og hvem man troede på eller helligede stedet og viet til. Og stednavnene viser os glimt af vore forfædres psyke, af deres skønhedsbegreber og deres æstetiske sans. Hvorledes deres mere primitive billeddannende og abstraherende evne gav sig udslag i navneoverforelse - omtrent som når børn, der i leg har bidt en brodskorpe til og formet den, kalder den en hest, et hoved, en arm osv. - Og til s p r og e ts historie er stednavnene i virkeligheden uundværlige. Sprog- og navnestoffet fortæller om land og folk under tidens gang, alt hvad der ligger bag ved ordet, navnet: hvordan landet andrede udseende, skove svandt og sumpe blev tørlagt, hvordan slægt fulgte efter slægt. Fæ dør, frænder dør - - Men s proget s el v o g kærnen $\mathrm{j}$ det stedsbundnesprogstof blev båret videre, selv om også dette er under udviklingens lov. Det tjener os da til or dge ografiske studier inden for den større sammenhæng, til di a l e k tge og rafis $\mathrm{k}$ e afgrænsninger i det mindre område, og gennem de tids- og stedfastede navnelag til mere specielle $\mathrm{l} y \mathrm{dh}$ is t or is ke undersøgelser.

I følgende afsnit skal vi forsoge at anlægge sådanne synspunkter og gennem et overskue se, hvad stoffet kan bringe. 